\title{
Trends and Socioeconomic Factors in Smoking and Alcohol Consumption Among Chinese Adults: Evidence From National Health Service Surveys
}

Kehui Liu

Nanjing Medical University

\section{Yan Ding}

Nanjing Medical University

Xiang Lu

Nanjing Medical University

Zhonghua Wang ( $\nabla$ wzh04@njmu.edu.cn )

Nanjing Medical University https://orcid.org/0000-0001-8038-6086

\section{Research}

Keywords: Smoking, Alcohol, Trend, Socioeconomic factors

Posted Date: January 21st, 2021

DOI: https://doi.org/10.21203/rs.3.rs-151174/v1

License: (c) (i) This work is licensed under a Creative Commons Attribution 4.0 International License. Read Full License

Version of Record: A version of this preprint was published at Archives of Public Health on July 9th, 2021. See the published version at https://doi.org/10.1186/s13690-021-00646-9. 


\section{Abstract}

Background: Smoking and excessive drinking are risk factors for many diseases. With the rapid economic development in China, it is important to identify trends in smoking and alcohol consumption and factors that contribute to these behaviors to ensure the health of the population.

Methods: we analyzed pooled cross-sectional data from the fourth, fifth, and sixth National Health Service Surveys conducted in Jiangsu Province in 2008, 2013, and 2018, respectively. Trends in smoking and alcohol use were analyzed with descriptive statistics, and bivariate and multivariate logistic regression was used to identify contributing factors.

Results: Among total sample, smoking rate was $23.95 \%$, in which the incidence of mild, moderate and severe smoking was $5.75 \%$, $4.63 \%$ and $13.56 \%$, respectively; drinking rate was $23.29 \%$, in which non-excessive drinking and excessive drinking were $19.80 \%$ and $3.49 \%$, respectively. From 2008-2018, overall and light-to-moderate smoking rates first increased and then decreased while heavy smoking rate declined; and alcohol consumption increased while excessive drinking increased before decreasing. The varying tendency of smoking and drinking rates in urban area was similar to rural area, however there was a significant gap in incidence between urban and rural area. Socioeconomic factors, demographic, health-related and year variables were significant associated with smoking and drinking.

Conclusion: Preventive measures such as education and support services along with stricter regulations for tobacco and alcohol use are needed to improve public health in China.

\section{Background}

Smoking and excessive alcohol consumption have adverse effects on individual and public health as well as negative economic and social consequences. Smoking is a risk factor for several diseases and a major cause of death [1]. Tobacco control measures recommended by the World Health Organization (WHO) cover about 5 billion people; however, 59 countries including China still fail to reach the highest level of implementation [2]. Meanwhile, alcohol use has been linked to diseases such as liver and esophageal cancers and cirrhosis, epilepsy, homicides, and motor vehicle accidents [3]. According to the WHO's 2018 Global Status Report on Alcohol and Health, 3 million people worldwide-mostly men-die from alcohol-related diseases each year, constituting an enormous global public health burden. China's per capita alcohol consumption increased by $80 \%$ between 2005 and 2018 [4].

Most countries recognize the importance of addressing the global tobacco and alcohol epidemic to protect the health of their citizens. In February 2005, the WHO promulgated the Framework Convention on Tobacco Control [5], and China issued the Health China 2030 plan in 2016 that outlined specific measures to promote healthy individual behaviors and lifestyles such as quitting smoking and limiting alcohol consumption [6]. According to the WHO, by the end of 2018, 125 countries or regions had formulated tobacco control laws or comprehensive legislation on smoking in public places [7]. As of August 2019, 22 cities in China had implemented local or national regulations to control smoking that cover 15\% of the population [8]. The WHO's 2010 Global Strategy to Reduce the Harmful Use of Alcohol represents an international consensus that reducing the harmful use of alcohol and its associated health and social burdens is a public health priority [9]. According to the WHO's 2018 Global Survey on Alcohol and Health, 11 countries have banned the purchase or consumption of alcohol [4].

A prerequisite for the successful implementation of measures to prevent smoking and alcohol use is identifying factors that influence these behaviors [10]. Many studies have investigated the impact of socioeconomic factors on smoking and alcohol consumption, although they focused on different factors. For example, one study that analyzed data from 54 low- and middleincome countries found differences in tobacco use according to socioeconomic status in low-income countries and there was significant variability among countries, especially those with the lowest incomes [11]. It has been demonstrated that high education level has a positive effect on health and healthy behaviors, whereas a low level of education is positively correlated with unhealthy behaviors such as smoking and drinking [12-14]. Socioeconomic factors such as occupation, education, and wealth were shown to be related to smoking, which was more common among individuals with a low-skill occupation and low education and income levels [15]. On the other hand, people in better health, with higher income and education levels, and who were more socially active were found to be more likely to consume harmful levels of alcohol [16]. There is also evidence that smoking and drinking behaviors 
are influenced by demographic factors such as age, sex, marital status, and location of residence; for example, studies conducted in China reported that people living in rural areas were more likely to smoke and drink than urban dwellers [17-19].

Most previous studies on the factors influencing smoking and drinking behavior have analyzed cross-sectional data, which do not reflect long-term trends. Moreover, there is a large gap in development between urban and rural areas in China, but there have been few comparative analyses of smoking and drinking rates according to location. To address these issues, the present study analyzed trends in smoking and alcohol consumption rates and quantities in urban and rural areas as well as factors contributing to these behaviors based on National Health Service Survey (NHSS) data from Jiangsu Province, China. The pooled cross-sectional data encompassed the period of rapid economic and social development and health reforms that occurred between 2008 and 2018. The results of our study can guide the development and implementation of more effective strategies to improve public health in China.

\section{Methods}

\section{Data source}

Since 1993, the NHSS has been organized every 5 years by the National Health Commission of China, with the provincial health commission being responsible for the survey of each region. The NHSS mainly consists of a household survey supplemented with an institutional survey; the former collects data through household interviews, with all permanent residents of surveyed households interviewed by trained and qualified investigators according to questionnaire items. A multistage stratified cluster random sampling method was used to select 156 counties (cities and districts) from 31 provinces in China; 5 towns (streets) were randomly selected in each of the sample counties (city or district); 2 villages (neighborhood committees) were randomly selected in each sample town (street), and 60 households were randomly selected in each sample village (neighborhood committees), for a total of 93,600 households (population of nearly 300,000). The fourth NHSS was in June 2008, with 7021 respondents participating in the survey; the fifth NHSS was in June 2013, with 10,422 respondents; and the sixth NHSS was in September 2018, with 11,550 respondents. We used data from 2008, 2013, and 2018 to analyze trends in and socioeconomic factors contributing to smoking and alcohol consumption among Chinese adults. The inclusion criteria were men and women over 15 years of age. After merging the NHSS datasets, the study population comprised 24,939 respondents. To ensure more accurate data analysis, respondents with any missing variables were excluded.

NHSS data provides detailed information on demographic characteristics, socioeconomic status, health status, healthcare use and cost, health behaviors, etc [20]. The structure of the questionnaire has good reliability and validity.

\section{Variables selection}

\section{Dependent variable}

The dependent variables were smoking, smoking quantity, drinking, and drinking quantity. Data on smoking were collected by asking respondents whether they smoked, the number of years they had smoked, and the average number of cigarettes smoked per day. The smoking index (SI) was calculated as number of years of smoking $\times$ average number of cigarettes per day; smoking quantity was categorized as low/light smoking $(\mathrm{SI} \leq 200)$, moderate $(200<\mathrm{SI}<400)$, or high/heavy smoking (SI $\geq 400)[21]$. Data on drinking were obtained by asking respondents whether they drink and how often; drinking quantity was converted to standard drinking units by the investigators. Specifically, 1 can of beer was equivalent to 1 drinking unit; $50 \mathrm{~g}$ of a beverage with $<40 \%$ alcohol was taken as equivalent to 1.5 drinking units; $50 \mathrm{~g}$ of a beverage with $\geq 40 \%$ alcohol was equivalent to 2 drinking units; 1 bottle of beer was equivalent to 2 drinking units; $500 \mathrm{~g}$ of wine was equivalent to 5 drinking units; and $500 \mathrm{~g}$ of yellow rice wine was equivalent to 6.5 drinking units. Drinking quantity was categorized as non-excessive or excessive drinking; the latter was defined as $\geq 5$ and $\geq 4$ drinking units at a time for men and women, respectively [22].

\section{Independent variables}

The independent variables were demographic information, socioeconomic status, and health-related information. Demographic variables (eg, age, sex, number of siblings, marital status, place of residence, and social health insurance) were included in our

Page $3 / 23$ 
analyses in order to reduce the impact of differences between rural and urban populations. Socioeconomic factors included income level, education level, employment status, type of occupation, and poor or low-security households. We used per capita annual income adjusted by price index as the income variable. Health-related variables included chronic disease, European Quality of Life Scale - 5 Dimensions (EQ-5D) score, health status, physical examination, and physical exercise. Self-reported health status was evaluated in the questionnaire with the Visual Analog Scale (VAS) and classified into 5 grades as in previous studies [23, 24]. Additionally, the wave variable $(2008,2013$, and 2018) was included in order to account for fluctuations in smoking and drinking rates within each year of the NHSS. Detailed descriptions of dependent and independent variables are shown in Table 1. 
Table 1

Description of explanatory variables

\begin{tabular}{|c|c|c|}
\hline & Description & Indicator/survey questions \\
\hline \multicolumn{3}{|l|}{$\begin{array}{l}\text { Dependent } \\
\text { variable }\end{array}$} \\
\hline \multirow[t]{2}{*}{ Smoking } & $0=\mathrm{No}$ & \multirow[t]{2}{*}{ Question:What is your current smoking status? } \\
\hline & $1=$ Yes & \\
\hline \multirow[t]{4}{*}{ Smoking quantity } & $0=$ No smoking & \multirow{4}{*}{$\begin{array}{l}\text { According to the smoking index (smoking index = number of cigarettes per } \\
\text { day * number of years of smoking), the smoking amount is divided into mild, } \\
\text { moderate and severe. }\end{array}$} \\
\hline & 1 = Low (light smoking) & \\
\hline & 2 = Moderate & \\
\hline & $\begin{array}{l}3 \text { = High (heavy } \\
\text { smoking) }\end{array}$ & \\
\hline \multirow[t]{2}{*}{ Drinking } & $0=$ No & \multirow[t]{2}{*}{ Question: Did you drink in the past six months? } \\
\hline & $1=$ Yes & \\
\hline \multirow[t]{3}{*}{ Drinking volume } & $0=$ No drinking & \multirow{3}{*}{$\begin{array}{l}\text { Judging whether to drink too much according to the } 2007 \text { standard of China } \\
\text { chronic disease and its risk factors monitoring report. }\end{array}$} \\
\hline & $\begin{array}{l}1 \text { = Non-excessive } \\
\text { drinking }\end{array}$ & \\
\hline & 2 = Excessive drinking & \\
\hline \multicolumn{3}{|l|}{$\begin{array}{l}\text { Independent } \\
\text { variable }\end{array}$} \\
\hline \multicolumn{3}{|l|}{$\begin{array}{l}\text { Demographic } \\
\text { factor }\end{array}$} \\
\hline \multirow[t]{3}{*}{ Age, years } & $1=15-45$ & \multirow[t]{3}{*}{ Question: Year of birth. } \\
\hline & $2=46-59$ & \\
\hline & $3=\geq 60$ & \\
\hline \multirow[t]{2}{*}{ Sex } & $0=$ Male & \multirow[t]{2}{*}{ Question: What is your gender? } \\
\hline & 1 = Female & \\
\hline \multirow{3}{*}{$\begin{array}{l}\text { Number of } \\
\text { siblings }\end{array}$} & $1=\leq 2$ & \multirow[t]{3}{*}{ Question: What is your household registration number $\square$} \\
\hline & $2=3$ or 4 & \\
\hline & $3=\geq 5$ & \\
\hline \multirow[t]{3}{*}{ Marital status } & 1 = Unmarried & \multirow[t]{3}{*}{ Question: What is your present marital status? } \\
\hline & $2=$ Married & \\
\hline & $\begin{array}{l}3= \\
\text { Divorced/widowed/other }\end{array}$ & \\
\hline \multirow[t]{2}{*}{$\begin{array}{l}\text { Place of } \\
\text { residence }\end{array}$} & $0=$ Urban & \multirow[t]{2}{*}{ Question: Where do you live? Urban or rural areas? } \\
\hline & $1=$ Rural & \\
\hline $\begin{array}{l}\text { Social health } \\
\text { insurance }\end{array}$ & $0=$ No & Question: Do you participate in social medical insurance? \\
\hline
\end{tabular}




\begin{tabular}{|c|c|c|}
\hline & Description & Indicator/survey questions \\
\hline & \multicolumn{2}{|l|}{$1=$ Yes } \\
\hline \multicolumn{3}{|l|}{$\begin{array}{l}\text { Socioeconomic } \\
\text { factor }\end{array}$} \\
\hline \multirow[t]{5}{*}{ Income level } & 1 = Very $\operatorname{low}(\leq 12453)$ & \multirow{5}{*}{$\begin{array}{l}\text { Yearly household income divided by the number of household members; first } \\
\text { household member with a weight of } 1 \text {, all following household members with } \\
\text { a weight of } 0.5 \text {. }\end{array}$} \\
\hline & $2=\operatorname{Low}(12453 \sim 20000)$ & \\
\hline & $\begin{array}{l}3=\operatorname{Middle}(20000 \sim \\
29284)\end{array}$ & \\
\hline & $4=\operatorname{High}(29284 \sim 43773)$ & \\
\hline & $5=$ Very high $(\geq 43773)$ & \\
\hline \multirow[t]{4}{*}{ Education } & 1 = Primary school & \multirow[t]{4}{*}{ Question: What's the highest level of education in last waves? } \\
\hline & 2 = Junior school & \\
\hline & $3=$ High school & \\
\hline & 4 = University or higher & \\
\hline \multirow{3}{*}{$\begin{array}{l}\text { Employment } \\
\text { status }\end{array}$} & 1 = Employed & \multirow[t]{3}{*}{ Question: What is your present employment situation $\square$} \\
\hline & $2=$ Retired & \\
\hline & $3=$ Unemployed & \\
\hline \multirow{3}{*}{$\begin{array}{l}\text { Type of } \\
\text { occupation }\end{array}$} & 1 = Unskilled labor & \multirow[t]{3}{*}{ Question:What is your occupation type? } \\
\hline & $2=$ Skilled labor & \\
\hline & $3=$ Other or unemployed & \\
\hline \multirow{2}{*}{$\begin{array}{l}\text { Poor or low- } \\
\text { security } \\
\text { household }\end{array}$} & $0=$ No & \multirow[t]{2}{*}{ Question: Is your family listed as a local poor or low-income family? } \\
\hline & $1=$ Yes & \\
\hline \multicolumn{3}{|l|}{$\begin{array}{l}\text { Health-related } \\
\text { factor }\end{array}$} \\
\hline \multirow[t]{2}{*}{ Chronic disease } & $0=$ No & \multirow[t]{2}{*}{ Question: Have you had a chronic disease diagnosed by your doctor? } \\
\hline & $1=$ Yes & \\
\hline \multirow[t]{2}{*}{$\begin{array}{l}\text { Multiple chronic } \\
\text { diseases }\end{array}$} & $0=\mathrm{No}$ & \multirow[t]{2}{*}{$\begin{array}{l}\text { "Yes" is defined as having two or more chronic diseases, and "no" is defined } \\
\text { as not suffering from chronic diseases. }\end{array}$} \\
\hline & $1=$ Yes & \\
\hline \multirow[t]{2}{*}{ EQ-5D } & $0=$ Complete health & \multirow{2}{*}{$\begin{array}{l}\text { "Complete health" is defined as EQ-5D score equal to one point, while } \\
\text { "incomplete health" is defined as EQ-5D score less than one point. }\end{array}$} \\
\hline & $1=$ Incomplete health & \\
\hline \multirow{3}{*}{$\begin{array}{l}\text { Health status } \\
\text { (VAS, self- } \\
\text { reported) }\end{array}$} & $1=$ Poor $(0-40)$ & \multirow[t]{3}{*}{$\begin{array}{l}\text { Health status on a } 20 \mathrm{~cm} \text { vertical scale with end points of } 0 \text { and } 100 \text { was } \\
\text { asked on the day of the interview. }\end{array}$} \\
\hline & $2=$ Moderate $(41-60)$ & \\
\hline & $3=$ Good $(41-80)$ & \\
\hline
\end{tabular}




\begin{tabular}{|c|c|c|}
\hline & Description & Indicator/survey questions \\
\hline & \multicolumn{2}{|l|}{0 = Excellent $(81-100)$} \\
\hline \multirow[t]{2}{*}{$\begin{array}{l}\text { Physical } \\
\text { examination }\end{array}$} & $0=\mathrm{No}$ & $\begin{array}{l}\text { Question: have you had a physical examination in the past } 12 \text { months? } \\
\text { (excluding examination due to illness) }\end{array}$ \\
\hline & $1=$ Yes & \\
\hline \multirow{4}{*}{$\begin{array}{l}\text { Physical exercise } \\
\text { (no. times per } \\
\text { week) }\end{array}$} & $1=\geq 6$ & $\begin{array}{l}\text { Question: on average, how many times a week do you exercise in the past } 1 \\
\text { month? }\end{array}$ \\
\hline & $2=3-5$ & \\
\hline & $3=1$ or 2 & \\
\hline & $4=0$ & \\
\hline \multirow[t]{3}{*}{ Wave } & $1=2008$ & \\
\hline & $2=2013$ & \\
\hline & $3=2018$ & \\
\hline
\end{tabular}

\section{Data analysis}

All statistical analyses were performed with Stata v14.0 software (Stata Corp, College Station, TX, USA) including descriptive statistics and bivariate and multivariate logistic regression analyses. $P<0.05$ was statistically significant in all tests. We first evaluated whether there were statistically significant differences between respondents from urban and rural areas with the chisquared test. We then calculated the rate and quantity of smoking and drinking in each year, and analyze the trends from 2008 to 2018. As smoking and drinking were binary variables, we used a bivariate logistic regression model to analyze factors influencing these behaviors based on the odds ratio (OR); and as smoking quantity and drinking quantity were multi-category variables, we used a multivariate logistic regression model to analyze the influencing factors based on the relative risk ratio (RRR).

\section{Results}

\section{Characteristics of the study population}

The characteristics of the study population are shown in Table 2. Of the 24,939 respondents, 10,684 (42.84\%) lived in urban areas and $14,255(57.1 \%)$ in rural areas. The overall rate of smoking was $23.95 \%$, with $5.75 \%$ light, $4.63 \%$ moderate, and $13.56 \%$ heavy smokers. Among residents of rural areas, $24.29 \%$ were smokers, with $5.55 \%$ light, $4.48 \%$ moderate, and $14.27 \%$ heavy smokers. In urban areas, $23.48 \%$ of the population smoked, with $6.03 \%$ light, $4.84 \%$ moderate, and $12.62 \%$ heavy smokers. Light and moderate smoking rates were significantly higher whereas the heavy smoking rate was lower in urban areas as compared to rural areas $(p<$ 0.001). The overall rate of alcohol use was $23.29 \%$, with $3.49 \%$ of the population engaging in excessive drinking. Drinking rates in urban and rural areas were $23.70 \%$ and $77.02 \%$, respectively. The non-excessive drinking rate was higher in urban areas than in rural areas $(20.83 \%$ vs $19.02 \%, p<0.001)$, while the opposite was true for excessive drinking rate $(2.86 \%$ vs $3.96 \%, p<0.001)$.

Rural and urban populations differed significantly with respect to most of the independent variables. Education level and personal annual income were significantly higher for urban respondents than for rural respondents: the proportions of respondents with high or very high income were $30.8 \%$ and $30.06 \%$, respectively, for the former group and $15.74 \%$ and $8.64 \%$, respectively, for the latter. The proportions of urban respondents with a high school education or university or higher education level were $23.93 \%$ and $23.19 \%$, respectively, which were significantly higher than the proportions of rural respondents $(15.11 \%$ and $6.03 \%$, respectively). The rates of employment and unemployment were significantly lower in urban areas (50.25\% and $17.23 \%$, respectively) than in rural areas ( $78.23 \%$ and $18.6 \%$, respectively), while the proportion of retirees was higher in urban as compared to rural areas ( $32.52 \%$ vs 
$3.17 \%)$. The proportion of poor or low-security households was larger in rural areas (4.39\%) than in urban areas (2.59\%). In terms of health-related variables, the rate of chronic diseases was higher in the urban population $(37.23 \%)$ than among rural residents $(27.45 \%)$; the latter were also less likely to have participated in physical examinations ( $38.69 \%$ vs $57.35 \%)$. 
Table 2

Characteristics of the study population

\begin{tabular}{|c|c|c|c|c|}
\hline Variable & All & Urban & Rural & $P$ value \\
\hline Total & 24939 & $10684(42.84 \%)$ & $14255(57.1 \%)$ & \\
\hline Smoking & & & & $P=0.138$ \\
\hline No & 18967(76.05\%) & $8175(76.52 \%)$ & $10792(75.71 \%)$ & \\
\hline Yes & $5972(23.95 \%)$ & $2509(23.48 \%)$ & $3463(24.29 \%)$ & \\
\hline Smoking quantity & & & & $P<0.001$ \\
\hline No smoking & 18967(76.05\%) & $8175(76.52 \%)$ & 10792(75.71\%) & \\
\hline Low (light smoking) & $1435(5.75 \%)$ & $644(6.03 \%)$ & $791(5.55 \%)$ & \\
\hline Moderate & $1155(4.63 \%)$ & $517(4.84 \%)$ & $638(4.48 \%)$ & \\
\hline High (heavy smoking) & $3382(13.56 \%)$ & $1348(12.62 \%)$ & $2034(14.27 \%)$ & \\
\hline Drinking & & & & $P=0.185$ \\
\hline No & 19131(76.71\%) & $8152(76.30 \%)$ & $10979(77.02 \%)$ & \\
\hline Yes & $5808(23.29 \%)$ & $2532(23.70 \%)$ & $3276(22.98 \%)$ & \\
\hline Drinking quantity & & & & $P<0.001$ \\
\hline No drinking & 19131(76.71\%) & $8152(76.30 \%)$ & $10979(77.02 \%)$ & \\
\hline Non-excessive drinking & 4932(19.80\%) & $2226(20.83 \%)$ & 2712(19.02\%) & \\
\hline Excessive drinking & $873(3.49 \%)$ & $306(2.86 \%)$ & $564(3.96 \%)$ & \\
\hline \multicolumn{5}{|l|}{ Demographic factor } \\
\hline Age, years & & & & $P<0.001$ \\
\hline $15-45$ & 9954(39.91\%) & $3905(36.55 \%)$ & $6049(42.43 \%)$ & \\
\hline $46-59$ & $7252(29.08 \%)$ & $2900(27.14 \%)$ & $4352(30.53 \%)$ & \\
\hline$\geq 60$ & 7733(31.01\%) & $3879(36.31 \%)$ & $3854(27.04 \%)$ & \\
\hline Sex & & & & $P=0.691$ \\
\hline Male & $12200(48.92 \%)$ & $5211(48.77 \%)$ & $6989(49.03 \%)$ & \\
\hline Female & $12739(51.08 \%)$ & $5473(51.23 \%)$ & $7266(50.97 \%)$ & \\
\hline Number of siblings & & & & $P<0.001$ \\
\hline$\leq 2$ & 6907(27.70\%) & $3470(32.48 \%)$ & $3437(24.11 \%)$ & \\
\hline 3 or 4 & 10738(43.06\%) & $4705(44.04 \%)$ & $6033(42.32 \%)$ & \\
\hline$\geq 5$ & $7294(29.25 \%)$ & $2509(23.48 \%)$ & $4785(33.57 \%)$ & \\
\hline Marital status & & & & $P=0.032$ \\
\hline Unmarried & $2520(10.10 \%)$ & $1089(10.19 \%)$ & $1431(10.04 \%)$ & \\
\hline Married & $20516(82.26 \%)$ & $8727(81.68 \%)$ & $11789(82.70 \%)$ & \\
\hline Divorced/widowed/other & 1903(7.63\%) & $868(8.12 \%)$ & $1035(7.26 \%)$ & \\
\hline
\end{tabular}




\begin{tabular}{|c|c|c|c|c|}
\hline Variable & All & Urban & Rural & $P$ value \\
\hline Social health insurance & & & & $P=0.0830$ \\
\hline No & $862(3.46 \%)$ & $394(3.69 \%)$ & $468(3.28 \%)$ & \\
\hline Yes & $24077(96.54 \%)$ & 10290(96.31\%) & $13787(96.72 \%)$ & \\
\hline \multicolumn{5}{|l|}{ Socioeconomic factor } \\
\hline Income level & & & & $P<0.001$ \\
\hline Very low & $5522(22.14 \%)$ & $657(6.15 \%)$ & 4865(34.13\%) & \\
\hline Low & $4518(18.12 \%)$ & $1291(12.08 \%)$ & $3227(22.64 \%)$ & \\
\hline Middle & $4921(19.73 \%)$ & $2233(20.90 \%)$ & 2688(18.86\%) & \\
\hline High & $5535(22.19 \%)$ & $3291(30.80 \%)$ & 2244(15.74\%) & \\
\hline Very high & $4443(17.82 \%)$ & $3212(30.06 \%)$ & $1231(8.64 \%)$ & \\
\hline Education & & & & $P<0.001$ \\
\hline Primary school & 8327(33.39\%) & $2256(21.12 \%)$ & $6071(42.59 \%)$ & \\
\hline Junior school & 8564(34.34\%) & $3393(31.76 \%)$ & $5171(36.27 \%)$ & \\
\hline High school & $4711(18.89 \%)$ & $2557(23.93 \%)$ & $2154(15.11 \%)$ & \\
\hline University or higher & 3337 (13.38\%) & $2478(23.19 \%)$ & $859(6.03 \%)$ & \\
\hline Employment status & & & & $P<0.001$ \\
\hline Employed & $16521(66.25 \%)$ & $5369(50.25 \%)$ & $11152(78.23 \%)$ & \\
\hline Retired & $3926(15.74 \%)$ & $3474(32.52 \%)$ & $452(3.17 \%)$ & \\
\hline Unemployed & $4492(18.01 \%)$ & $1841(17.23 \%)$ & $2651(18.60 \%)$ & \\
\hline Type of occupation & & & & $P<0.001$ \\
\hline Unskilled labor & $5236(21.00 \%)$ & $3979(37.24 \%)$ & $1257(8.82 \%)$ & \\
\hline Skilled labor & $14078(56.45 \%)$ & $4154(38.88 \%)$ & $9924(69.62 \%)$ & \\
\hline Other or unemployed & $5625(22.56 \%)$ & $2551(23.88 \%)$ & $3074(21.56 \%)$ & \\
\hline Poor or low-security household ${ }^{\dagger}$ & & & & $P<0.001$ \\
\hline No & $24036(96.38 \%)$ & 10407(97.41\%) & $13629(95.61 \%)$ & \\
\hline Yes & $903(3.62 \%)$ & $277(2.59 \%)$ & $626(4.39 \%)$ & \\
\hline \multicolumn{5}{|l|}{ Health related factor } \\
\hline Chronic disease & & & & $\mathrm{P}<0.001$ \\
\hline No & $17048(68.36 \%)$ & $6706(62.77 \%)$ & $10342(72.55 \%)$ & \\
\hline Yes & $7891(31.64 \%)$ & $3978(37.23 \%)$ & $3913(27.45 \%)$ & \\
\hline Multiple chronic diseases & & & & $P<0.001$ \\
\hline No & $23067(92.49 \%)$ & $9664(90.45 \%)$ & $13403(94.02 \%)$ & \\
\hline Yes & $1872(7.51 \%)$ & $1020(9.55 \%)$ & $852(5.98 \%)$ & \\
\hline
\end{tabular}




\begin{tabular}{|c|c|c|c|c|}
\hline Variable & All & Urban & Rural & $P$ value \\
\hline EQ-5D & & & & $P=0.101$ \\
\hline Complete health & $20721(83.09 \%)$ & $8829(82.64 \%)$ & $11892(83.42 \%)$ & \\
\hline Incomplete health & $4218(16.91 \%)$ & 1855(17.36\%) & $2363(16.58 \%)$ & \\
\hline Health status & & & & $P<0.001$ \\
\hline Poor $(0-40)$ & $345(1.39 \%)$ & $136(1.27 \%)$ & $209(1.46 \%)$ & \\
\hline Moderate $(41-60)$ & $2388(9.58 \%)$ & 1052(9.85\%) & 1336(9.37\%) & \\
\hline Good (41-80) & $9910(39.74 \%)$ & $4542(42.51 \%)$ & $5368(37.66 \%)$ & \\
\hline Excellent $(81-100)$ & $12296(49.30 \%)$ & $4954(46.37 \%)$ & $7342(51.50 \%)$ & \\
\hline Physical examination & & & & $P<0.001$ \\
\hline No & $13297(53.32 \%)$ & $4557(42.65 \%)$ & $8740(61.31 \%)$ & \\
\hline Yes & $11642(46.68 \%)$ & $6127(57.35 \%)$ & $5515(38.69 \%)$ & \\
\hline Physical exercise (no. times per week) & & & & $P<0.001$ \\
\hline$\geq 6$ & $4879(19.56 \%)$ & $3442(32.22 \%)$ & $1437(10.08 \%)$ & \\
\hline $3-5$ & $2304(9.24 \%)$ & $1346(12.60 \%)$ & $958(6.72 \%)$ & \\
\hline 1 or 2 & 1858(7.45\%) & 1104(10.33\%) & $754(5.29 \%)$ & \\
\hline 0 & $15898(63.75 \%)$ & $4792(44.85 \%)$ & $11106(77.91 \%)$ & \\
\hline Wave & & & & $P<0.001$ \\
\hline 2008 & $5987(24.01 \%)$ & $1385(12.96 \%)$ & $4602(32.28 \%)$ & \\
\hline 2013 & $9194(36.87 \%)$ & $4208(39.39 \%)$ & $4986(34.98 \%)$ & \\
\hline 2018 & $9758(39.13 \%)$ & $5091(47.65 \%)$ & $4667(32.74 \%)$ & \\
\hline \multicolumn{5}{|c|}{${ }^{\dagger}$ Poor or low-security households are low-income groups subsidized by the government. } \\
\hline Abbreviations: EQ-5D, European Quality & f Life Scale - 5 & nensions. & & \\
\hline
\end{tabular}

\section{Trends in smoking and alcohol consumption}

The smoking rate increased from $23.95 \%$ in 2008 to $25.33 \%$ in 2013 but decreased to $25.33 \%$ in 2018 (Fig. 1). In 2008 and 2013 , the smoking rate was higher in rural areas $(26.11 \%$ and $24.4 \%$, respectively) than in urban areas $(24.41 \%$ and $22.45 \%$, respectively), but this was reversed in 2018 (22.24\% vs 23\%). Similar trends were observed in light and moderate smoking rates (Figs. 2 and 3 ). However, the rate of heavy smoking showed a continuously declining trend over time (Fig. 4). Additionally, while the rates of light, moderate, and heavy smoking were higher in rural areas as compared to urban areas in 2008 (light: $2.76 \%$ vs $2.67 \%$; moderate: $3.91 \%$ vs $3.68 \%$; heavy: $17.73 \%$ vs $16.1 \%$ ), the reverse was true in 2018 (light: $6.41 \%$ vs $6.78 \%$; moderate: $4.69 \%$ vs $4.95 \%$; heavy: $11.14 \%$ vs $11.27 \%)$.

Drinking rates increased from $13.58 \%$ in 2008 to $23.8 \%$ in 2013 and $28.77 \%$ in 2018 (Fig. 5). The rate was higher in rural areas than in urban areas in 2008 (14.97\% vs 8.95\%) and 2013 (24.87\% vs 22.53\%), but was comparable between the 2 locations in 2018 (rural: $28.86 \%$ vs urban: $28.68 \%$ ). The overall rate of excessive drinking increased from $3.76 \%$ in 2008 to $5.06 \%$ in 2013 , and then decreased to 1.88\% in 2018 (Fig. 5). Similar trends were observed in urban areas (2008: 1.81\%, 2013: 4.61\%; 2018: 1.71\%) and rural areas (2008: 4.32\%; 2013: 5.42\%; 2018: 2.04\%). It is worth noting that drinking and excessive drinking rates were significantly 
higher in rural as compared to urban areas throughout the survey period; however, the rates in urban areas increased more dramatically from 2008 to 2013, such that the differences between urban and rural areas shrank from 2013 to 2018.

\section{Factors associated with smoking rate and quantity}

After controlling for confounding variables, we found that smoking rate and quantity differed significantly between rural and urban areas (Table 3). Rural respondents were $30 \%$ less likely to smoke $(\mathrm{OR}=0.07), 22 \%$ less likely to be light smokers $(\mathrm{RRR}=0.78), 36 \%$ less likely to be moderate smokers ( $R R R=0.64)$, and $30 \%$ less likely to be heavy smokers $(R R R=0.3)$. Other demographic factors also influenced smoking rate and quantity. Older respondents ( $\geq 46$ years) were more likely to smoke, less likely to be light or moderate smokers, and more likely to be heavy smokers than respondents who were $\leq 45$ years old. Smoking was less common in women than in men $(\mathrm{OR}=0.02)$, and the rates of light, moderate, and heavy smoking were lower in women than in men $(R R R=0.18$, 0.01 , and 0.01 , respectively). Married people were more likely to smoke than those who were unmarried $(\mathrm{OR}=2.56)$; this was true for light ( $R R R=1.24)$, moderate ( $R R R=10.07)$, and heavy $(R R R=4.53)$ smoking. People with social health insurance were less likely to smoke $(O R=0.7)$, whether lightly $(R R R=0.58)$, moderately $(R R R=0.72)$, or heavily $(R R R=0.7)$. Socioeconomic status influenced smoking rate and quantity: compared to people with very low income, those with a very high income were more likely to smoke (OR $=1.18)$ and to be moderate ( $R R R=1.26)$ or heavy ( $R R R=1.28)$ smokers. There was a significant inverse correlation between smoking rate and education level, with an especially close correlation observed for the rate of heavy smoking. Compared to respondents who were employed, those who were unemployed or retired people were $~ 50 \%$ less likely to smoke, whether lightly, moderately, or heavily.

People with multiple chronic diseases were less likely to smoke $(\mathrm{OR}=0.78)$ and smoke heavily $(\mathrm{RRR}=0.75)$. Compared to respondents who were in very good health, people with poor health were significantly less likely to smoke $(O R=0.57)$ and smoke heavily $(R R R=0.49)$. EQ-5D scores also indicated that the rates of smoking $(O R=0.81)$ and heavy smoking $(R R R=0.75)$ were significantly lower in respondents with incomplete health than in those with complete health. Compared to people who did not have regular physical examinations, those who had undergone a physical examination in the previous 12 months were less likely to smoke $(\mathrm{OR}=0.91)$ and smoke heavily $(R R R=0.9)$. People who did not engage in physical exercise were more likely to smoke $(\mathrm{OR}=$ $1.35)$-including smoking moderately $(R R R=1.24)$ and heavily $(R R R=1.47)$-than those who exercised regularly. 
Table 3

Results of regression analysis of smoking rate and quantity

\begin{tabular}{|c|c|c|c|c|c|c|c|c|}
\hline \multirow[b]{2}{*}{ Variable } & \multicolumn{2}{|c|}{ Smoking } & \multicolumn{2}{|c|}{ Light smoking } & \multicolumn{2}{|c|}{ Moderate smoking } & \multicolumn{2}{|c|}{ Heavy smoking } \\
\hline & OR & $95 \% \mathrm{Cl}$ & RRR & $95 \% \mathrm{Cl}$ & RRR & $95 \% \mathrm{Cl}$ & RRR & $95 \% \mathrm{Cl}$ \\
\hline \multicolumn{9}{|l|}{ Demographic factor } \\
\hline \multicolumn{9}{|l|}{ Age, years (ref: 15-45) } \\
\hline $46-59$ & $1.43^{\star \star \star}$ & $(1.29,1.58)$ & $0.34 * \star \star$ & $(0.28,0.40)$ & 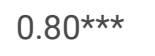 & $(0.68,0.95)$ & $4.92^{\star \star \star}$ & $(4.27,5.68)$ \\
\hline$\geq 60$ & $1.43^{\star \star \star}$ & $(1.25,1.64)$ & $0.25^{\star \star \star}$ & $(0.19,0.33)$ & $0.58^{\star \star \star}$ & $(0.45,0.75)$ & 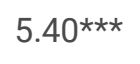 & $(4.52,6.45)$ \\
\hline \multicolumn{9}{|l|}{ Sex (ref: male) } \\
\hline Female & $0.02^{\star \star \star}$ & $(0.01,0.02)$ & $0.18^{* \star *}$ & $(0.01,0.02)$ & $0.01^{\star \star \star}$ & $(0.01,0.02)$ & 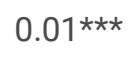 & $(0.01,0.02)$ \\
\hline \multicolumn{9}{|l|}{$\begin{array}{l}\text { Number of siblings (ref: } \\
1 \text { or } 2 \text { ) }\end{array}$} \\
\hline 3 or 4 & 0.99 & $(0.90,1.09)$ & $0.84^{\star}$ & $(0.70,1.01)$ & 1.04 & $(0.88,1.24)$ & 1.05 & $(0.93,1.17)$ \\
\hline$\geq 5$ & 1.02 & $(0.91,1.11)$ & 1.07 & $(0.90,1.30)$ & 0.86 & $(0.71,1.04)$ & 0.92 & $(0.81,1.03)$ \\
\hline \multicolumn{9}{|l|}{$\begin{array}{l}\text { Marital status (ref: } \\
\text { unmarried) }\end{array}$} \\
\hline Married & $2.56^{\star \star \star}$ & $(2.21,2.97)$ & $1.24^{\star \star}$ & $(1.03,1.50)$ & $10.07 * \star \star$ & $(6.01,15.58)$ & $4.53^{\star \star \star}$ & $(3.41,6.03)$ \\
\hline Divorced/widowed/other & 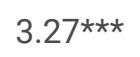 & $(2.64,4.04)$ & 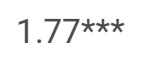 & $(1.24,2.53)$ & $12.41 * \star \star$ & $(7.40,20.84)$ & $5.13^{\star \star \star}$ & $(3.69,7.13)$ \\
\hline \multicolumn{9}{|l|}{$\begin{array}{l}\text { Place of residence (ref: } \\
\text { urban) }\end{array}$} \\
\hline Rural & $0.70 * \star \star$ & $(0.64,0.77)$ & $0.78^{\star \star \star}$ & $(0.67,0.90)$ & $0.64^{\star \star \star}$ & $(0.54,0.75)$ & 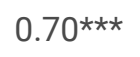 & $(0.62,0.79)$ \\
\hline \multicolumn{9}{|l|}{$\begin{array}{l}\text { Social health insurance } \\
\text { (ref: no) }\end{array}$} \\
\hline Yes & 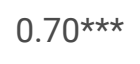 & $(0.57,0.86)$ & $0.58^{\star \star \star}$ & $(0.43,0.77)$ & $0.72^{\star}$ & $(0.51,1.02)$ & $0.70 * \star$ & $(0.53,0.92)$ \\
\hline \multicolumn{9}{|l|}{ Socioeconomic factor } \\
\hline \multicolumn{9}{|l|}{ Income (ref: very low) } \\
\hline Low & 1.02 & $(0.90,1.15)$ & 1.03 & $(0.84,1.28)$ & 0.99 & $(0.79,1.23)$ & 1.02 & $(0.88,1.18)$ \\
\hline Middle & 1.02 & $(0.90,1.16)$ & 1.04 & $(0.83,1.29)$ & 0.89 & $(0.71,1.13)$ & 1.03 & $(0.88,1.20)$ \\
\hline High & 1.06 & $(0.93,1.21)$ & 0.96 & $(0.77,1.20)$ & 1.06 & $(0.84,1.33)$ & 1.1 & $(0.94,1.29)$ \\
\hline Very high & $1.18^{\star \star}$ & $(1.02,1.40)$ & 1 & $(0.78,1.27)$ & $1.26^{\star}$ & $(0.98,1.62)$ & $1.28^{\star \star \star}$ & $(1.07,1.53)$ \\
\hline \multicolumn{9}{|l|}{$\begin{array}{l}\text { Education (ref: primary } \\
\text { school) }\end{array}$} \\
\hline Junior school & $0.85^{\star \star \star}$ & $(0.77,0.94)$ & 1.03 & $(0.84,1.26)$ & $1.19 *$ & $(0.99,1.44)$ & $0.83^{\star \star \star}$ & $(0.74,0.93)$ \\
\hline High school & $0.68^{\star \star *}$ & $(0.60,0.77)$ & 1.11 & $(0.89,1.39)$ & $0.80 * \star$ & $(0.63,1.00)$ & $0.56^{\star \star *}$ & $(0.48,0.65)$ \\
\hline University or higher & $0.30 * \star \star$ & $(0.25,0.36)$ & $0.55^{\star \star \star}$ & $(0.42,0.72)$ & $0.24^{\star \star \star}$ & $(0.17,0.33)$ & $0.18^{\star \star \star}$ & $(0.14,0.23)$ \\
\hline $\begin{array}{l}\text { Employment status (ref: } \\
\text { employed) }\end{array}$ & & & & & & & & \\
\hline
\end{tabular}

${ }^{*} \mathrm{P}<0.05, * \star \mathrm{P}<0.01, * \star * \mathrm{P}<0.001$

Abbreviations: Cl, confidence interval; EQ-5D, European Quality of Life Scale - 5 Dimensions; OR, odds ratio; ref: reference; RRR, relative risk ratio. 


\begin{tabular}{|c|c|c|c|c|c|c|c|c|}
\hline \multirow[b]{2}{*}{ Retired } & \multicolumn{2}{|c|}{ Smoking } & \multicolumn{2}{|c|}{ Light smoking } & \multicolumn{2}{|c|}{ Moderate smoking } & \multicolumn{2}{|c|}{ Heavy smoking } \\
\hline & $0.49 \star \star \star$ & $(0.43,0.57)$ & $0.52^{\star \star \star}$ & $(0.38,0.72)$ & $0.48^{\star \star \star}$ & $(0.36,0.64)$ & $0.54^{\star \star \star}$ & $(0.46,0.64)$ \\
\hline Unemployed & $0.51^{\star \star \star}$ & $(0.42,0.63)$ & $0.33^{\star \star \star}$ & $(0.23,0.48)$ & 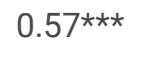 & $(0.39,0.83)$ & $0.60 * \star \star$ & $(0.46,0.77)$ \\
\hline \multicolumn{9}{|c|}{$\begin{array}{l}\text { Type of occupation (ref: } \\
\text { unskilled labor) }\end{array}$} \\
\hline Skilled labor & $0.83^{\star \star \star}$ & $(0.75,0.92)$ & $0.87^{\star}$ & $(0.74,1.02)$ & $0.80^{\star \star}$ & $(0.67,0.96)$ & $0.87 *$ & $(0.76,1.00)$ \\
\hline Unemployed or other & 1.03 & $(0.85,1.24)$ & 0.82 & $(0.61,1.10)$ & 1.04 & $(0.76,1.46)$ & 1.16 & $(0.93,1.46)$ \\
\hline \multicolumn{9}{|l|}{$\begin{array}{l}\text { Poor or low-security } \\
\text { household (ref: no) }\end{array}$} \\
\hline Yes & 1.05 & $(0.86,1.29)$ & 0.89 & $(0.61,1.30)$ & 0.83 & $(0.55,1.25)$ & $1.21+$ & $(0.96,1.53)$ \\
\hline \multicolumn{9}{|l|}{ Health-related factor } \\
\hline \multicolumn{9}{|c|}{ Chronic disease (ref: no) } \\
\hline Yes & 0.94 & $(0.86,1.03)$ & 0.93 & $(0.77,1.11)$ & 1.02 & $(0.86,1.21)$ & 0.95 & $(0.85,1.06)$ \\
\hline \multicolumn{9}{|l|}{$\begin{array}{l}\text { Multiple chronic } \\
\text { diseases (ref: no) }\end{array}$} \\
\hline Yes & $0.78^{\star \star \star}$ & $(0.67,0.92)$ & 0.99 & $(0.71,1.38)$ & 0.83 & $(0.61,1.11)$ & $0.75^{\star \star \star}$ & $(0.63,0.90)$ \\
\hline \multicolumn{9}{|l|}{$\begin{array}{l}\text { EQ-5D (ref: complete } \\
\text { health) }\end{array}$} \\
\hline Incomplete health & $0.81^{\star \star \star}$ & $(0.72,0.91)$ & 0.98 & $(0.78,1.23)$ & 0.94 & $(0.76,1.16)$ & $0.75^{\star \star \star}$ & $(0.65,0.85)$ \\
\hline \multicolumn{9}{|l|}{$\begin{array}{l}\text { Health status (ref: } \\
\text { excellent) }\end{array}$} \\
\hline Poor $(0-40)$ & $0.57 \star \star \star$ & $(0.39,0.82)$ & 0.81 & $(0.39,1.70)$ & 0.56 & $(0.27,1.16)$ & $0.49 * * \star$ & $(0.32,0.77)$ \\
\hline Moderate $(41-60)$ & 0.95 & $(0.81,1.09)$ & 1 & $(0.74,1.35)$ & 0.96 & $(0.73,1.27)$ & 0.93 & $(0.78,1.11)$ \\
\hline Good (41-80) & 1.08 & $(0.99,1.17)$ & 1.01 & $(0.88,1.16)$ & 0.9 & $(0.78,1.05)$ & $1.15^{\star \star \star}$ & $(1.03,1.27)$ \\
\hline \multicolumn{9}{|l|}{$\begin{array}{l}\text { Physical examination } \\
\text { (ref: no) }\end{array}$} \\
\hline Yes & $0.91^{\star *}$ & $(0.84,0.98)$ & 1 & $(0.88,1.13)$ & 0.92 & $(0.80,1.06)$ & $0.90 * \star$ & $(0.81,0.99)$ \\
\hline \multicolumn{9}{|c|}{$\begin{array}{l}\text { Physical exercise, no. of } \\
\text { times per week (ref: } \geq 6 \text { ) }\end{array}$} \\
\hline $3-5$ & 0.94 & $(0.81,1.10)$ & 0.87 & $(0.68,1.11)$ & 0.97 & $(0.74,1.27)$ & 0.94 & $(0.77,1.14)$ \\
\hline 1 or 2 & $1.24^{\star \star}$ & $(1.05,1.46)$ & 1.05 & $(0.82,1.35)$ & $1.31 *$ & $(0.99,1.73)$ & $1.25^{\star \star}$ & $(1.00,1.56)$ \\
\hline 0 & $1.35^{\star \star \star}$ & $(1.21,1.50)$ & 1.12 & $(0.94,1.34)$ & $1.24^{\star \star}$ & $(1.02,1.50)$ & $1.47 \star \star \star$ & $(1.29,1.68)$ \\
\hline \multicolumn{9}{|l|}{ Wave (ref: 2008) } \\
\hline 2013 & 1.09 & $(0.98,1.21)$ & $3.29 * \star \star$ & $(2.67,4.04)$ & $1.40 * \star \star$ & $(1.14,1.71)$ & $0.62^{\star \star \star}$ & $(0.55,0.71)$ \\
\hline 2018 & 0.98 & $(0.88,1.10)$ & $3.10 * \star \star$ & $(2.52,3.83)$ & $1.33^{\star \star \star}$ & $(1.08,1.63)$ & $0.52^{\star \star \star}$ & $(0.46,0.60)$ \\
\hline \multicolumn{9}{|c|}{${ }^{*} \mathrm{P}<0.05, * * \mathrm{P}<0.01, * \star * \mathrm{P}<0.001$} \\
\hline
\end{tabular}




\section{Factors associated with drinking rate and quantity}

Demographic variables including age, sex, and marital status were significantly associated with drinking rate and quantity (Table 4). People $\geq 46$ years old were more likely to consume alcohol than those $\leq 45$ years old, whereas the $46-59$ year age group was more likely to drink excessively than people $\leq 45$ years $(R R R=1.55)$. Women were less likely to drink than men $(O R=0.05)$, including drinking excessively $(R R R=0.01)$. Married people were more likely to drink than those who were unmarried people $(\mathrm{OR}=$ $3.26)$ and to engage in non-excessive ( $R R R=3.2)$ and excessive $(R R R=3.49)$ drinking. Alcohol consumption was positively correlated with income level and negatively correlated with education level. People with high school-level education or higher were less likely to drink than those with primary school or lower education, whether this consisted of non-excessive or excessive drinking. Compared to employed respondents, those who were retired $(O R=0.64)$ or unemployed $(O R=0.73)$ were less likely to drink and to drink excessively $(R R R=0.54, R R R=0.57)$.

Chronic disease, health status, and physical exercise were significantly associated with drinking rate and quantity. People with a chronic disease were significantly more likely to drink excessively than those without a chronic disease $(R R R=1.18)$, while those with $\geq 2$ chronic diseases were significantly less likely to drink than those without chronic diseases $(O R=0.73)$, whether the drinking was excessive $(R R R=0.49)$ or not $(R R R=0.76)$. A lower level of health was associated with a lower alcohol consumption rate. People who did little physical exercise were more likely to drink and drink excessively than those who exercised regularly $(\mathrm{OR}=$ $1.10, \mathrm{RRR}=1.25$ ). 
Table 4

Results of regression analysis of drinking rate and quantity

\begin{tabular}{|c|c|c|c|c|c|c|}
\hline \multirow[t]{2}{*}{ Variable } & \multicolumn{2}{|l|}{ Drinking } & \multicolumn{2}{|c|}{ Non-excessive drinking } & \multicolumn{2}{|c|}{ Excessive drinking } \\
\hline & OR & $95 \% \mathrm{Cl}$ & RRR & $95 \% \mathrm{Cl}$ & RRR & $95 \% \mathrm{Cl}$ \\
\hline \multicolumn{7}{|l|}{ Demographic factor } \\
\hline \multicolumn{7}{|l|}{ Age, years (ref: 15-45) } \\
\hline $46-59$ & 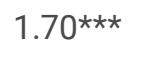 & $(1.54,1.88)$ & $1.73^{\star \star \star}$ & $(1.56,1.93)$ & $1.55^{\star \star \star}$ & $(1.28,1.87)$ \\
\hline$\geq 60$ & $1.41^{\star \star \star}$ & $(1.23,1.61)$ & $1.53^{\star * *}$ & $(1.33,1.76)$ & 0.87 & $(0.66,1.15)$ \\
\hline \multicolumn{7}{|l|}{ Sex (ref: male) } \\
\hline Female & $0.05^{\star \star \star}$ & $(0.04,0.05)$ & $0.05^{\star * *}$ & $(0.05,0.06)$ & $0.01^{\star * *}$ & $(0.01,0.02)$ \\
\hline \multicolumn{7}{|c|}{ Number of siblings (ref: 1 or 2) } \\
\hline 3 or 4 & 0.96 & $(0.88,1.06)$ & 0.98 & $(0.89,1.08)$ & 0.86 & $(0.71,1.03)$ \\
\hline$\geq 5$ & 0.94 & $(0.85,1.03)$ & 0.95 & $(0.85,1.05)$ & 0.86 & $(0.70,1.06)$ \\
\hline \multicolumn{7}{|c|}{ Marital status (ref: unmarried) } \\
\hline Married & 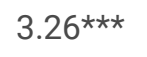 & $(2.78,3.82)$ & 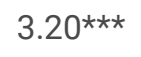 & $(2.70,3.74)$ & $3.49 \star \star \star$ & $(2.45,4.98)$ \\
\hline Divorced/widowed/other & $2.81^{\star \star \star}$ & $(2.26,3.49)$ & $2.83^{\star \star \star}$ & $(2.25,3.56)$ & $2.39 \star \star$ & $(1.43,3.99)$ \\
\hline \multicolumn{7}{|c|}{ Place of residence (ref: urban) } \\
\hline Rural & 1.02 & $(0.94,1.12)$ & 1 & $(0.92,1.10)$ & 1.15 & $(0.95,1.38)$ \\
\hline \multicolumn{7}{|c|}{ Social health insurance (ref: no) } \\
\hline Yes & 0.92 & $(0.75,1.14)$ & 0.93 & $(0.74,1.17)$ & 0.9 & $(0.60,1.35)$ \\
\hline \multicolumn{7}{|l|}{ Socioeconomic factor } \\
\hline \multicolumn{7}{|l|}{ Income (ref: very low) } \\
\hline Low & $1.20 * \star \star$ & $(1.07,1.36)$ & $1.18^{\star \star}$ & $(1.04,1.34)$ & $1.32^{\star \star}$ & $(1.04,1.68)$ \\
\hline Middle & $1.31^{\star \star \star}$ & $(1.16,1.49)$ & 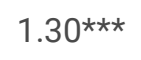 & $(1.14,1.48)$ & $1.42^{\star \star \star}$ & $(1.11,1.82)$ \\
\hline High & $1.36^{\star \star *}$ & $(1.19,1.54)$ & $1.33^{\star \star \star}$ & $(1.16,1.52)$ & $1.51^{\star \star \star}$ & $(1.16,1.96)$ \\
\hline Very high & $1.39 * * *$ & $(1.21,1.60)$ & $1.32^{* * *}$ & $(1.14,1.53)$ & $1.94^{\star \star \star}$ & $(1.45,2.60)$ \\
\hline \multicolumn{7}{|c|}{ Education (ref: primary school) } \\
\hline Junior school & 0.94 & $(0.85,1.03)$ & 0.96 & $(0.86,1.06)$ & $0.82^{\star \star}$ & $(0.67,1.00)$ \\
\hline High school & $0.75^{\star \star \star}$ & $(0.67,0.85)$ & $0.77^{\star \star \star}$ & $(0.68,0.87)$ & $0.67 * \star \star$ & $(0.53,0.86)$ \\
\hline University or higher & $0.58^{\star \star \star}$ & $(0.50,0.69)$ & $0.63^{\star \star \star}$ & $(0.54,0.75)$ & 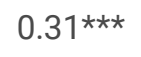 & $(0.26,0.53)$ \\
\hline \multicolumn{7}{|c|}{ Employment status (ref: employed) } \\
\hline Retired & 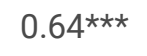 & $(0.56,0.74)$ & $0.67 * \star \star$ & $(0.57,0.76)$ & $0.54 * \star \star$ & $(0.39,0.75)$ \\
\hline Unemployed & $0.73^{\star \star \star}$ & $(0.60,0.89)$ & $0.77^{\star \star}$ & $(0.63,0.96)$ & $0.57^{\star \star \star}$ & $(0.38,0.84)$ \\
\hline \multicolumn{7}{|c|}{ Type of occupation (ref: unskilled labor) } \\
\hline Skilled labor & 0.93 & $(0.84,1.03)$ & 0.95 & $(0.86,1.06)$ & $0.81^{\star *}$ & $(0.66,0.99)$ \\
\hline Unemployed or other & 0.88 & $(0.74,1.06)$ & $0.84^{\star}$ & $(0.69,1.02)$ & 1.02 & $(0.74,1.40)$ \\
\hline
\end{tabular}




\begin{tabular}{|c|c|c|c|c|c|c|}
\hline \multirow{2}{*}{$\begin{array}{l}\text { Variable } \\
\text { Yes }\end{array}$} & \multicolumn{2}{|l|}{ Drinking } & \multicolumn{2}{|c|}{ Non-excessive drinking } & \multicolumn{2}{|c|}{ Excessive drinking } \\
\hline & 0.88 & $(0.71,1.08)$ & 0.85 & $(0.69,1.06)$ & 1.03 & $(0.67,1.58)$ \\
\hline \multicolumn{7}{|c|}{ Health-related factor } \\
\hline \multicolumn{7}{|c|}{ Chronic disease (ref: no) } \\
\hline Yes & 1.01 & $(0.94,1.12)$ & 0.99 & $(0.90,1.08)$ & $1.18^{\star}$ & $(0.98,1.41)$ \\
\hline \multicolumn{7}{|c|}{ Multiple chronic diseases (ref: no) } \\
\hline Yes & $0.73^{\star * *}$ & $(0.63,0.85)$ & $0.76^{\star * \star}$ & $(0.65,0.90)$ & $0.49 * * *$ & $(0.33,0.73)$ \\
\hline \multicolumn{7}{|c|}{ EQ-5D (ref: complete health) } \\
\hline Incomplete health & 1.05 & $(0.94,1.18)$ & 1.08 & $(0.96,1.21)$ & 0.83 & $(0.63,1.09)$ \\
\hline \multicolumn{7}{|c|}{ Health status (ref: excellent) } \\
\hline Poor $(0-40)$ & $0.35^{\star \star \star}$ & $(0.24,0.52)$ & $0.39 * \star \star$ & $(0.26,0.58)$ & $0.09 * \star$ & $(0.01,0.66)$ \\
\hline Moderate $(41-60)$ & $0.63^{* * *}$ & $(0.54,0.74)$ & $0.62^{\star \star \star}$ & $(0.53,0.72)$ & $0.78+$ & $(0.56,1.09)$ \\
\hline Good $(41-80)$ & $0.92^{\star \star}$ & $(0.85,0.99)$ & 0.93 & $(0.86,1.02)$ & $0.85^{\star \star}$ & $(0.72,1.00)$ \\
\hline \multicolumn{7}{|c|}{ Physical examination (ref: no) } \\
\hline Yes & 1.05 & $(0.97,1.13)$ & 1.05 & $(0.97,1.13)$ & 1.06 & $(0.90,1.24)$ \\
\hline \multicolumn{7}{|c|}{ Physical exercise, no. of times per week (ref: $\geq 6$ ) } \\
\hline $3-5$ & 0.91 & $(0.78,1.05)$ & 0.9 & $(0.77,1.04)$ & 1 & $(0.72,1.39)$ \\
\hline 1 or 2 & $1.17 *$ & $(1.00,1.36)$ & $1.19 \star \star$ & $(1.02,1.40)$ & 1 & $(0.69,1.45)$ \\
\hline 0 & $1.10 *$ & $(0.99,1.22)$ & 1.08 & $(0.97,1.20)$ & $1.25^{\star}$ & $(0.99,1.57)$ \\
\hline \multicolumn{7}{|l|}{ Wave (ref: 2008) } \\
\hline 2013 & $2.11 * \star \star$ & $(1.89,2.36)$ & $2.29 \star \star \star *$ & $(2.03,2.59)$ & $1.63^{\star \star \star}$ & $(1.33,1.99)$ \\
\hline 2018 & $3.29 * \star \star$ & $(2.94,3.68)$ & $4.13^{\star \star \star}$ & $(3.66,4.67)$ & 0.83 & $(0.65,1.05)$ \\
\hline
\end{tabular}

\section{Discussion}

In this study, we analyzed pooled cross-sectional data from the NHSS of Jiangsu Province to identify trends in smoking and alcohol consumption and associated socioeconomic factors. The overall smoking rate and light and moderate smoking rates increased from 2008 to 2013 and then decreased from 2013 to 2018, while the heavy smoking rate declined continuously from 2008 to 2018. The latter trend may be attributable to the establishment of tobacco control laws and regulations, increases in tobacco tax rates and prices, and prohibition of tobacco advertising along with other measures implemented by the Chinese government to curb tobacco use. Additionally, a general increase in health awareness and adoption of healthier living habits as a result of social and economic development may have contributed to the decline. The smoking rate was higher in rural areas than in urban areas in 2008, regardless of whether the smoking was light, moderate, or heavy. However, the trend was reversed in 2018. This may be related to the acceleration of urbanization and the influx of rural residents into cities in recent years. At the end of $2018,59.58 \%$ of permanent residents in China lived in urban areas, representing an increase of $8.31 \%$ from 2011 ; meanwhile, $43.37 \%$ of registered residents lived in cities, representing an increase of $3.47 \%$ from 2015 . Thus, the higher smoking rate in urban as compared to rural areas in $\mathbf{2 0 1 8}$ may be the result of a combination of the more frequent social interactions among city dwellers and the large number of smokers from rural areas who migrated to cities.

The rate of alcohol use increased continuously between 2008 and 2018 while the rate of excessive drinking increased from 2008 to 2013 but then declined from 2013 to 2018, consistent with previous reports [25, 26]. Although drinking and excessive drinking rates were higher in rural as compared to urban areas from 2008 to 2018, from 2008 to 2013, the rates increased more precipitously in 
urban areas such that by 2018, the difference between the 2 locations had shrunk. In Chinese culture, drinking is an important way to relieve stress and socialize, and many people regard drinking as a normal habit in rural areas or as serving a social facilitator role in city life. Thus, in order to reduce the rates of alcohol-related diseases and injuries, regulatory policies restricting alcohol use as well as health education are needed. Income level was significantly associated with smoking and drinking rates and quantities. Smoking rate was reported to be higher among people who were poor than among the wealthy [27, 28]. However, in accordance with previous findings [29], we found that income level was positively associated with smoking rate, with the highest income group having more smokers, especially moderate and heavy smokers. The rate of alcohol use-especially excessive drinking-also increased with income level, which is supported by earlier studies [16, 30, 31]. A possible explanation for these observations is the rapid economic development in China and associated increase in income levels, which has led to increased discretionary spending on tobacco and alcohol, especially among people who lack awareness of the adverse health consequences.

We found that education level was significantly associated with smoking and drinking rates: respondents with a higher education level were less likely to smoke and drink (and engage in heavy smoking or excessive drinking) than those with a lower education level, which is consistent with earlier findings [12-14, 32]. A higher educational level may be associated with a greater capacity for translating information into behaviors-in this case, controlling smoking and alcohol consumption. Therefore, improving education level is one strategy to increase health awareness and discourage tobacco and alcohol use in the Chinese population. Employment status was also associated with smoking and drinking behavior: both smoking and drinking rates were higher in employed respondents compared to those who were unemployed or retired, which could be related to pressure to socialize and engage with others (colleagues etc) through drinking. In terms of demographic and health-related variables, older people, men, and married people were more likely to smoke and drink alcohol than young people, women, and unmarried people, which is in agreement with other reports [33-35]. Heavy smoking and excessive drinking were also positively correlated with age. This may be because older people in China typically have a low level of education and are thus less likely to be aware of the negative health effects of smoking and drinking, and instead consider these as normal life activities. Additionally, smoking and drinking in women is poorly regarded in Chinese culture; hence, these behaviors are far more common in men. Finally, people who were in poor health (ie, had chronic disease[s]) were less likely to smoke and drink; this is likely because these individuals were incapable of tolerating the effects of tobacco and alcohol.

Compared to 2008, the rate of light and moderate smoking increased significantly in 2013 and 2018, while the rate of heavy smoking decreased. The latter likely reflects the implementation of tobacco control measures in China as well as increased health awareness in the population. However, there is still no national legislation on smoking in China and the smoking control standards set by the WHO have not been reached. In addition, drinking rate and quantity increased in 2013; by 2018, the rates of drinking and non-excessive drinking had increased significantly but the rate of excessive drinking was unchanged. Thus, excessive alcohol consumption remains a serious problem in China but may be difficult to curb, given the importance of drinking as a means of social bonding in Chinese culture.

The results of our analyses indicate that measures are needed to control smoking and alcohol use and promote healthy behaviors in China. Firstly, the government should use public awareness campaigns targeting people with middle or high income levels or low education level, or those living in urban areas. Secondly, the education level of people in rural areas and health awareness among the elderly should be promoted. Thirdly, health facilities (eg, hospitals) should provide more support services such as smoking cessation programs. Fourthly, smoking bans in public places must be strictly enforced by the authorities. Finally, China's tobacco tax is relatively low compared to that of other countries; increasing taxes on tobacco and alcohol is one way to discourage their consumption.

Our study had certain limitations. Firstly, we analyzed only NHSS data from Jiangsu Province, which may limit the generalizability of the observed trends. Additionally, we examined correlations but were unable to make causal inferences regarding the data.

Finally, our regression analysis focused on individual variables but did not examine the effects of interactions among variables on tobacco and alcohol consumption [36, 37].

\section{Conclusions}


Our results showed that the rate of heavy smoking declined from 2008 to 2018, while overall smoking and light and moderate smoking rates have recently decreased. Similar trends were observed in the rate of excessive alcohol consumption, but overall drinking rate increased continuously from 2008 to 2018. The trends in smoking and drinking rates were similar between urban and rural areas, although smoking rates were initially higher and then lower in rural areas as compared to urban areas. While drinking rates were higher in rural areas throughout the survey period, the rates rose steeply in urban areas such that the difference between the 2 locations had decreased by 2018. Socioeconomic factors such as income and education levels and work status as well as demographic and health-related variables influenced smoking and alcohol consumption rates. Preventive measures such as increasing education and awareness in key groups and providing technical and support services to control smoking and alcohol use are needed to more effectively promote public health in China.

\section{Abbreviations}

WHO: World Health Organization; NHSS: National Health Service Study; SI: Smoking Index; EQ-5D: European Quality of Life Scale 5 Dimensions; VAS: Visual Analog Scale.

\section{Declarations}

\section{Acknowledgments}

We would like to acknowledge the Chinese National Health Commission and the local Health Commission of Jiangsu province for their cooperation. We would also like to thank all study participants for their time to be interviewed.

\section{Author Contributions}

Conceptualization, K.L., Y.D. and Z.W.; methodology, K.L., Y.D. and Z.W.; validation, K.L., Y.D. and X.L.; formal analysis, K.L., X.L. Z.W.; investigation, K.L., Y.D. and X.L.; data curation, Z.W.; writing-original draft preparation, K.L.; writing-review and editing, K.L., Y.D. and Z.W.; supervision, Z.W.; All authors have read and agreed to the published version of the manuscript.

\section{Funding:}

This research was funded by the National Office for Philosophy and Social Sciences of China (No.18BGL243). The funding bodies were not involved in the design of the study, or data collection, analysis, and interpretation or in writing the manuscript.

\section{Availability of data and materials}

Data from this study can be obtained from the corresponding author upon reasonable request.

\section{Ethics approval and consent to participate}

This study was approved by the Academic Research Ethics Committee of Nanjing Medical University; reference number: 2020617

\section{Consent for publication}

Not applicable.

\section{Competing interests}

The authors declare no conflict of interest.

\section{References}

1. AlMulla Ahmad,HassanYassoub Norr,Fu Dongbo,ElAwa Fatimah,Alebshehy Raouf,Ismail Mahmoud,Fraser Charles P. Smoking cessation services in the Eastern Mediterranean Region: highlights and findings from the WHO Report on the Global Tobacco Epidemic 2019.[J]. Eastern Mediterranean health journal = La revue de sante de la Mediterranee orientale $=$ al-Majallah alsihhiyah li-sharq al-mutawassit,2020,26(1). 
2. WHO Report on the Global Tobacco Epidemic, 2019囚https://www.ersnet.org/the-society/news/who-publishes-2019-report-onthe-global-tobacco-epidemic(assessed on 31 July, 2019).

3. Anyinzaam-Adolipore John Nyaaba,Alhassan Abdul Rauf,Hammersley Richard H.. Sociodemographic Correlates of Alcohol Abuse in Kassena-Nankana Municipality, Ghana[J]. Journal of Addiction,2020,2020.

4. Global Status Report on Alcohol and Health囚2018:https://www.drugsandalcohol.ie/29701/(assessed on 28 September 2018).

5. Monitoring Tobacco Use and Prevention Policies: Perspective of WHO Report on the Global Tobacco Epidemic, 2017[J]. Journal of Nursing Science \& Practice,2019,9(2).

6. Central Committee of the Communist Party of China, State Council of the people's Republic of China. "Healthy China 2030" planning outline [J]. Chinese Journal of practical rural doctors, 2017,24 (7): 1-12 DOI:10.3969/j.issn.1672-7185.2017.07.002.

7. World Health Organization. 2018 Global progress report on implementation of the WHO Framework Convention on Tobacco Control[R]. Geneva: World Health Organization, 2018.

8. Yang Jie,Li Qing,Zhou Shuo,Xi Zi,Luo Xiaowei,Song Lili.Study on Chinese Urban Tobacco Control Regulations (2006-2019) [J].Capital Public Health,2019,13(05):226-229.

9. Jonathan Chick. The WHO Global Strategy to Reduce the Harmful Use of Alcohol[J]. Alcohol and Alcoholism,2011,46(3).

10. Batty G D, Bhaskar A, Emslie C, et al. Association of life course socioeconomic disadvantage with future problem drinking and heavy drinking: gender differentials in the west of Scotland[J]. International Journal of Public Health, 2012, 57(1):247-247.

11. Chandrashekhar T Sreeramareddy,Sam Harper,Linda Ernstsen. Educational and wealth inequalities in tobacco use among men and women in 54 low-income and middle-income countries[J]. Tobacco Control,2018,27(1).

12. Chatterji. Education and Health: Disentangling Causal Relationships from Associations[J]. Encyclopedia of Health Economics, 2014, 33(6):250-258.

13. Emma Stait, Michael Calnan. Are differential consumption patterns in health-related behaviours an explanation for persistent and widening social inequalities in health in England?[J]. International Journal for Equity in Health,2016,15(1).

14. Doku D , Darteh E K M , Kumi-Kyereme A. Socioeconomic inequalities in cigarette smoking among men: evidence from the 2003 and 2008 Ghana demographic and health surveys[J]. Archives of Public Health,71,1(2013-04-26), 2013, 71(1):9-9.

15. Doku D , Darteh E K M , Kumi-Kyereme A. Socioeconomic inequalities in cigarette smoking among men: evidence from the 2003 and 2008 Ghana demographic and health surveys[J]. Archives of Public Health,71,1(2013-04-26), 2013, 71(1):9-9.

16. Iparraguirre José. Socioeconomic determinants of risk of harmful alcohol drinking among people aged 50 or over in England. [J]. BMJ open,2015,5(7).

17. Di Cuiping. Study on smoking and drinking among residents aged 15 and above in Henan Province [D]. Zhengzhou University, 2019

18. Wang Ning, Feng Yajing, Bao Heling, et al. Investigation on smoking status of people aged 40 and above in China in 2014 [J]. Chinese Journal of epidemiology, 2018, 39 (5): 551-556

19. Lu Shurong, pan Xiaoqun, Xiang Quanyong, et al. Investigation on drinking behavior of urban and rural residents in Jiangsu Province [J]. China health education, 2011 (01): 54-56

20. National Bureau of Statistics. Sixth National Health Service Statistical Survey System; National Bureau of Statistics: Beijing, China. Available online: http://www.stats.gov.cn/tjfw/bmdcxmsp/bmzd/201809/t20180905_1621098.html (accessed on 5 September 2018).

21. Yuan Linlin. Analysis of the impact of social capital on smoking and drinking behavior of the elderly in China [D]. Shandong University, 2019

22. Chronic disease center of China Center for Disease Control and prevention. Surveillance report of chronic diseases and risk factors in China in 2007 [M]. People's Health Press, 2010

23. Xin-Xin J , Hong-Yan H U , Xuan-Xuan W , et al. Analysis on self-rated health status and its influencing factors among Chinese residents aged 15 and above[J]. Chinese Journal of Health Policy, 2016.

24. Wang J, Meng QY, Yip W, et al. Correlation between subjective well-being and health status of rural residents [J]. Journal of Shandong University. 2008;46(9):919-21.

25. Available online: http://www.who.int/news-room/fact-sheets/detail/alcohol (accessed on 24 October 2018)

Page 20/23 
26. Ruiyi Liu,Li Chen,Fan Zhang,Rui Zhu,Xinjie Lin,Xuchen Meng,Huabing Li,Xun Lei,Yong Zhao. Trends in Alcohol Intake and the Association between Socio-Demographic Factors and Volume of Alcohol Intake amongst Adult Male Drinkers in China[J]. International Journal of Environmental Research and Public Health,2019,16(4).

27. Xu Yong. Survey on smoking status of rural elderly population in Taicang City [J]. Jiangsu preventive medicine, 2015, 26 (5): 113-114

28. Zhang Rong, Cao Qian, Lu Yun. Analysis of smoking behavior and its influencing factors among urban and rural residents in China [J]. Acta tobacco Sinica, 2015, (2): 93-93

29. Ahmad Reza Hosseinpoor,Lucy Anne Parker,Edouard Tursan d'Espaignet,Somnath Chatterji. Socioeconomic inequality in smoking in low-income and middle-income countries: results from the World Health Survey.[J]. PLoS ONE,2017,7(8).

30. Ling J, Smith K, Wilson G, et al. The 'other' in patterns of drinking: a qualitative study of attitudes towards alcohol use among professional, managerial and clerical workers. BMC Public Health 2012;12:892.

31. Brierley-Jones L, Ling J, McCabe K, et al. Habitus of home and traditional drinking: a qualitative analysis of reported middleclass alcohol use. Sociol Health Illn 2014;36:1054-76.

32. Oshio $\mathrm{T}$, Kobayashi M . Association of smoking and drinking with socioeconomic factors: A comparative study based on bivariate probit model analysis[J]. Pie/cis Discussion Paper, 2010.

33. Srinivasa Vittal Katikireddi,Elise Whitley,Jim Lewsey,Linsay Gray,Alastair H Leyland. Socioeconomic status as an effect modifier of alcohol consumption and harm: analysis of linked cohort data[J]. The Lancet Public Health,2017,2(6).

34. Hu Ruying, Zhan Yuanyuan, Wang Meng, et al. Study on the trend of adult smoking behavior in Zhejiang Province. Preventive medicine. 2018,30 (12): 1189-1193

35. Zhang Miao, Cao Dan, Li Han, et al. Investigation on smoking status of community residents in Shenyang City and the cognition of smoking population on the relationship between smoking and cancer [J]. Practical preventive medicine, 2019,26 (01): 84-86

36. Henderson C, Liu X, Roux A V D , et al. The effects of US state income inequality and alcohol policies on symptoms of depression and alcohol dependence[J]. Social ence \& Medicine, 2004, 58(3):565-575.

37. Poortinga Wouter. Do health behaviors mediate the association between social capital and health?[J]. Preventive medicine,2006,43(6).

\section{Figures}

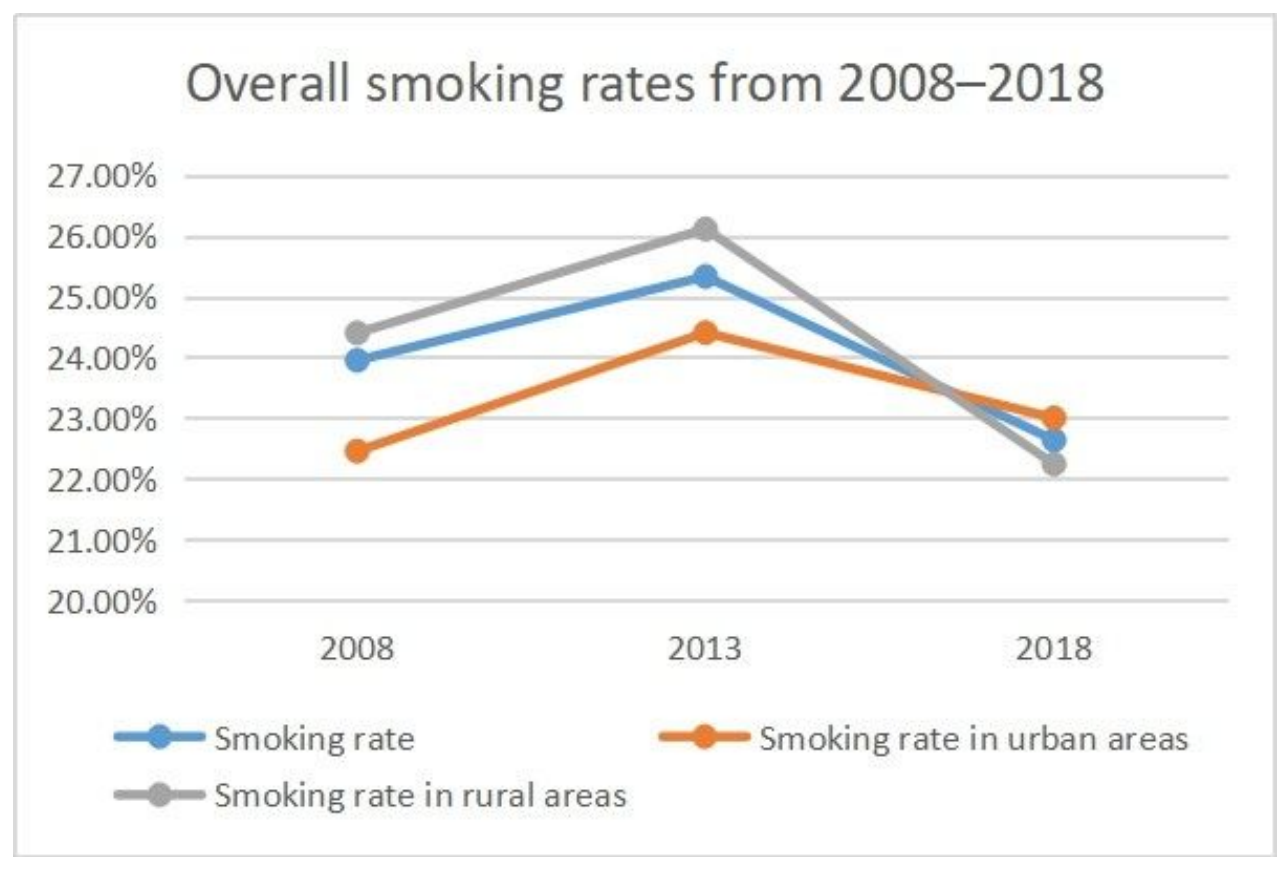

Figure 1

Page 21/23 


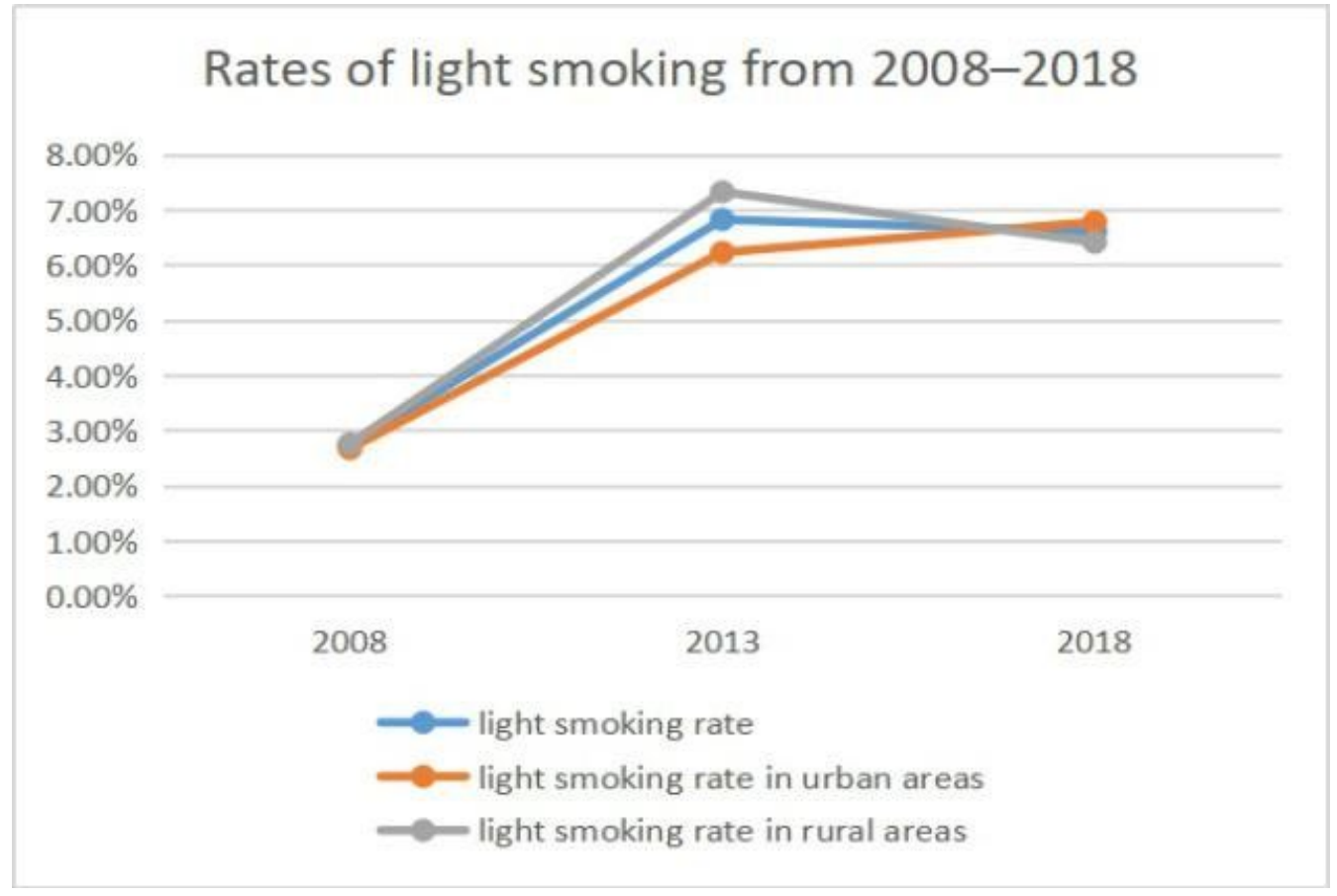

\section{Figure 2}

Rates of light smoking from 2008-2018.

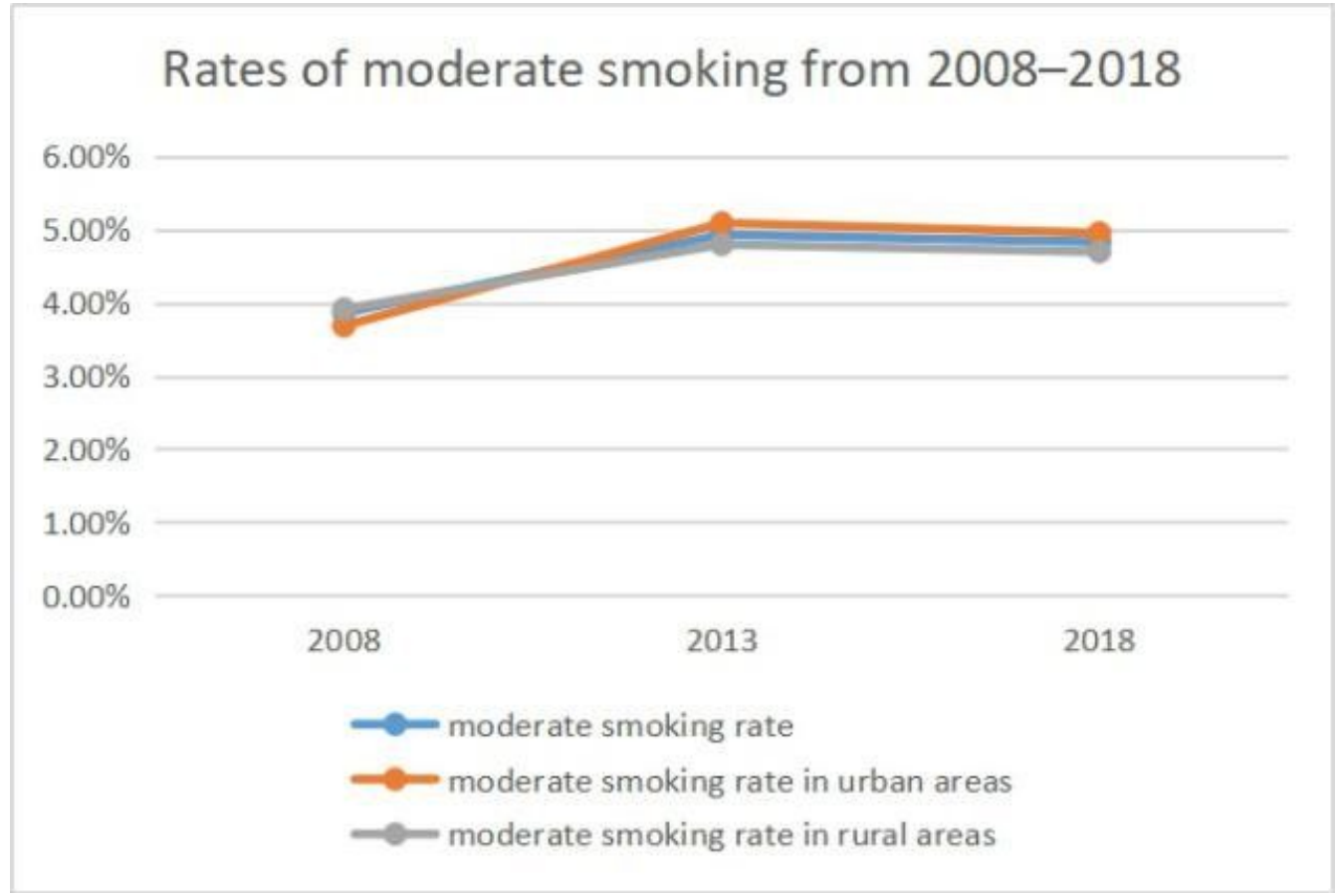

\section{Figure 3}

Rates of moderate smoking from 2008-2018. 


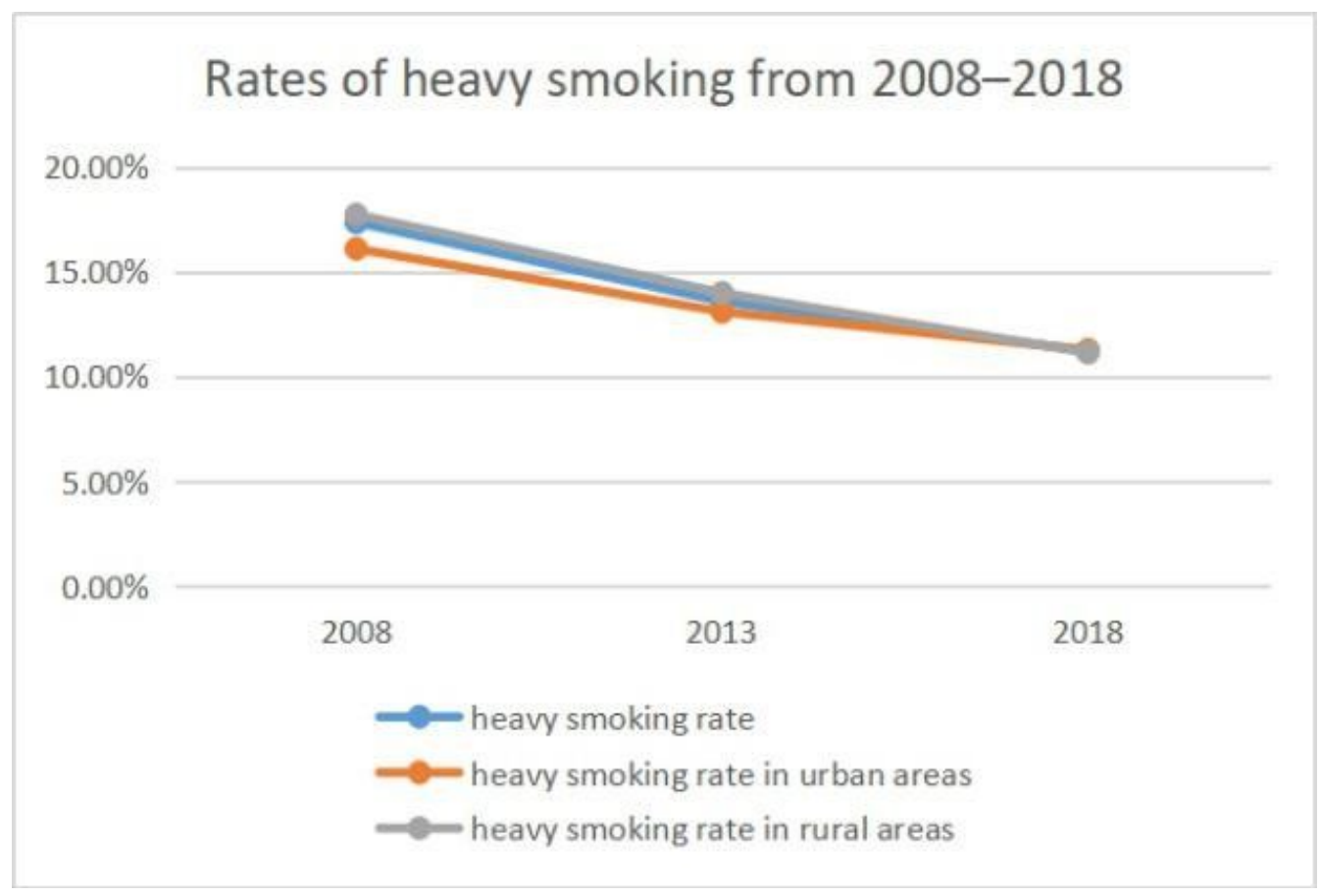

Figure 4

Rates of heavy smoking from 2008-2018.

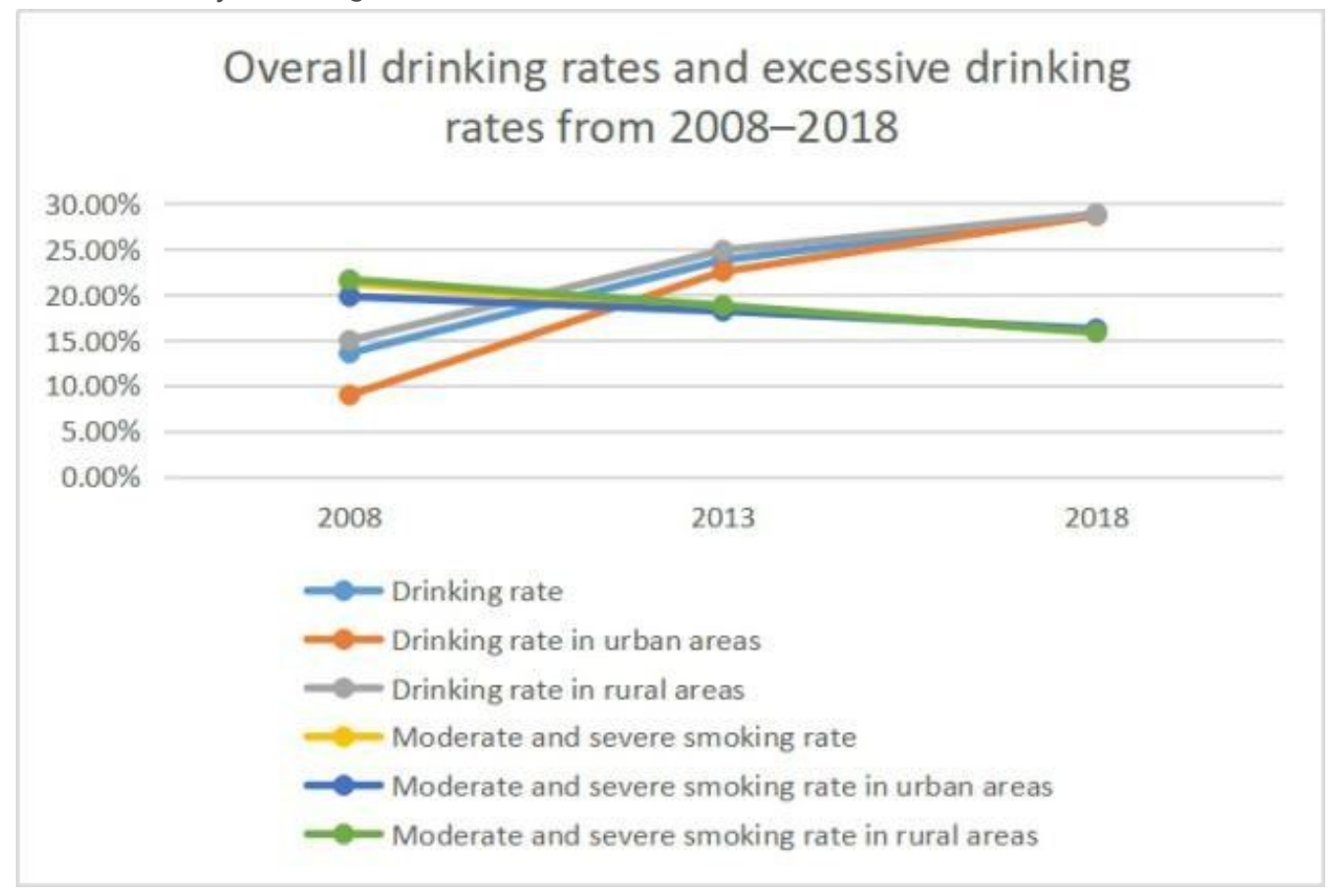

\section{Figure 5}

Overall drinking rates and excessive drinking rates from 2008-2018. 